\title{
RESPONSABILIDAD SOCIAL UNIVERSITARIA: COMUNICADO PÚBLICO iSI TODO ES BULLYING NADA ES BULLYING!!
}

Ante los últimos acontecimientos difundidos por los medios de comunicación, es preciso señalar lo siguiente:

La intimidación entre iguales (bullying) no es el único problema existente en los centros educativos, por lo que es necesario no olvidar "las otras violencias" que se producen en sus interiores, cuyos protagonistas no solo son los alumnos.

La violencia escolar no es ajena a las otras violencias que están presentes en la sociedad, entre ellas la violencia mediática que ha convertido a los noticieros en crónicas de muerte y sangre y el dolor en espectáculo.

Las últimas noticias del suicidio de una niña y una adolescente han sido atribuidas a la presencia de bullying en los centros educativos, conclusiones precipitadas que no contribuyen a entender la problemática que indudablemente es parte de la penosa realidad de los centros.

Es preocupante observar opiniones de profesionales de la salud, que tipifican cualquier violencia como bullying y fácilmente etiquetan a las personas a partir de indicios no verificados o presentan cifras alarmantes de los problemas, sin medir las consecuencias e impacto de sus opiniones, presentando en algunos casos imágenes deplorables del profesional psicólogo.

La intimidación entre iguales como parte de la problemática escolar requiere un trabajo sistemático y colaborativo del conjunto de la comunidad educativa que incluye a los alumnos, docentes, tutores, directivos y padres de familia. Ninguna intervención será eficaz si se desconoce las particularidades del centro educativo $\mathrm{y}$ se ignora a sus miembros.

En este contexto de emergencia es imperativo sensibilizar permanentemente a la comunidad educativa para no ser indiferente o guardar silencio ante casos de maltrato escolar y aplicar un conjunto de medidas urgentes en los centros educativos más vulnerables donde se detecten casos de intimidación.

La construcción de una cultura democrática es un desafío para la sociedad en su conjunto y en particular para los centros educativos. Todo ello requiere compromiso y decisión para lograrlo, no puede haber convivencia sin democracia en los centros educativos valorar y otorgar protagonismo a los alumnos a quienes hoy se les considera responsables del problema y que generalmente son los grandes 
ignorados en las propuestas de intervención; desde una visión positiva afirmamos que los jóvenes tienen extraordinarias potencialidades y mucha imaginación para aportar a la construcción de una sana convivencia; apostemos por ello.

Finalmente, Invocamos al Ministerio de Educación la consideración de plazas de psicólogos en su presupuesto y el cumplimiento de la Ley N. ${ }^{\circ} 29719$ (promueve la convivencia en las instituciones educativas) en todos sus alcances.

Ciudad Universitaria, julio de 2012

Dra. Lupe García

Decana de la Facultad de Psicología 